\title{
Ozone effects on wheat grain quality - A summary
}

\author{
Malin C. Broberg a, Zhaozhong Feng ${ }^{\mathrm{b}}$, Yue Xin ${ }^{\mathrm{b}}$, Håkan Pleijel ${ }^{\mathrm{a},{ }^{*}}$ \\ ${ }^{a}$ University of Gothenburg, Department of Biological and Environmental Sciences, P.O. Box 461, SE-40530 Göteborg, Sweden \\ ${ }^{\mathrm{b}}$ State Key Laboratory of Urban and Regional Ecology, Research Center for Eco-Environmental Sciences, Chinese Academy of Sciences, 18 Shuangqing Road, \\ Haidian District, Beijing 100085, China
}

\section{A R T I C L E I N F O}

\section{Article history:}

Received 23 September 2014

Received in revised form

4 December 2014

Accepted 6 December 2014

Available online 8 January 2015

\section{Keywords:}

Baking quality

Mineral

Ozone

Protein

Quality

Starch

1000-Grain weight

Volume weight

Wheat

\begin{abstract}
A B S T R A C T
We synthesized the effects of ozone on wheat quality based on 42 experiments performed in Asia, Europe and North America. Data were analysed using meta-analysis and by deriving response functions between observed effects and daytime ozone concentration. There was a strong negative effect on 1000grain weight and weaker but significant negative effects on starch concentration and volume weight. For protein and several nutritionally important minerals $(\mathrm{K}, \mathrm{Mg}, \mathrm{Ca}, \mathrm{P}, \mathrm{Zn}, \mathrm{Mn}, \mathrm{Cu})$ concentration was significantly increased, but yields were significantly decreased by ozone. For other minerals ( $\mathrm{Fe}, \mathrm{S}, \mathrm{Na}$ ) effects were not significant or results inconclusive. The concentration and yield of potentially toxic $\mathrm{Cd}$ were negatively affected by ozone. Some baking properties (Zeleny value, Hagberg falling number) were positively influenced by ozone. Effects were similar in different exposure systems and for spring and winter wheat. Ozone effects on quality should be considered in future assessments of food security/ safety.
\end{abstract}

๑) 2014 Elsevier Ltd. All rights reserved.

\section{Introduction}

Ground-level ozone $\left(\mathrm{O}_{3}\right)$ is an important regional to semi-global air pollutant and as well an anthropogenic greenhouse gas (Simpson et al., 2014). Tropospheric $\mathrm{O}_{3}$ is generated through photochemical reactions of so-called $\mathrm{O}_{3}$ precursors, i.e. nitrogen oxides $\left(\mathrm{NO}_{x}\right)$, volatile organic compounds (VOC) including methane $\left(\mathrm{CH}_{4}\right)$, and carbon monoxide (CO), which are all emitted from anthropogenic sources. Background $\mathrm{O}_{3}$ concentrations have risen from approximately $10 \mathrm{ppb}$ before the industrial revolution (Volz and Kley, 1988) to daytime summer concentrations exceeding $40 \mathrm{ppb}$ in many parts of the Northern Hemisphere (Vingarzan, 2004).

It is well established that current ozone concentrations are sufficiently high over large areas of the globe to cause significant adverse effects on crop production (Avnery et al., 2011; Van Dingenen et al., 2009). Wheat has been found to be a highly ozone sensitive crop (Feng and Kobayashi, 2009; Pleijel, 2011; Tai et al., 2014). There has been a strong focus on the effects of $\mathrm{O}_{3}$ on

\footnotetext{
* Corresponding author.

E-mail addresses: hakan.pleijel@bioenv.gu.se, hakan.pleijel@me.com (H. Pleijel).
}

quantitative yield in crops (e.g. Feng and Kobayashi, 2009; Mills et al., 2007; Tai et al., 2014) as well as effects on photosynthesis and other physiological aspects/processes such as senescence (e.g. Feng et al., 2008; Mulholland et al., 1997; Sandelius et al., 1995) which are important for the mechanistic understanding of growth effects and for modelling. Although some studies have included quality aspects (e.g. Fuhrer et al., 1990; Pleijel, 2012; Vandermeiren et al., 1992; Zheng et al., 2013), less attention has been paid to these when it comes to research syntheses and policy related work. This paper summarises what is known about the effects of $\mathrm{O}_{3}$ on wheat grain quality traits. The study is based on existing literature, but also includes some until now unpublished quality data for experiments already described in the literature, and covers experiments performed in Europe, North America and Asia.

Several quality traits exist for a crop like wheat. Some of these (primarily grain protein concentration, 1000-grain weight, volume weight, baking quality) may affect the market price of the yield. Others are nutritionally or otherwise important, but external to the market. These include e.g. the concentration of different nutrient mineral constituents and the content of the potentially toxic element $\mathrm{Cd}$.

Certain aspects of wheat quality are linked to physical characteristics such as the average 1000-grain weight (technically: the 
mass of 1000 grains) and volume weight (technically: the density or specific mass of grain). Low values of these variables indicate a large occurrence of small and malformed grains reducing the quality for use of the grain, while higher values generally are related to larger flour yield (Manley et al., 2009; Weiss and MorenoSotomayer, 2006). Another group of quality properties is the concentration of various nutrients including protein, macronutrients such as $\mathrm{Mg}, \mathrm{K}, \mathrm{Ca}, \mathrm{P}$ and $\mathrm{S}$ as well as micronutrients like $\mathrm{Zn}, \mathrm{Fe}, \mathrm{Mn}$ and $\mathrm{Cu}$. $\mathrm{Cd}$ is also of interest since bread is an important pathway for human intake of this potentially highly toxic, bioaccumulating element, which may have a number of important adverse health effects, for example on kidney and bone (Satarug et al., 2010). While the concentration of various grain mineral constituents is important from a qualitative perspective, also the unit area yields of these constituents are relevant for human nutrition and for biogeochemical considerations of the balance of input/output in the agroecosystems. In case the unit area yield of protein or minerals is reduced, this may significantly and negatively affect the ability of people to access sufficient protein and minerals in areas of food scarcity in addition to the loss of food energy caused by the $\mathrm{O}_{3}$ impairment of grain yield. Therefore we assess both $\mathrm{O}_{3}$ effects on concentrations and on the yield of these constituents.

Starch is the main source of energy in wheat grain, consisting often in the range of $60-70 \%$ of grain mass, and wheat is the second most important energy source for the human population. Thus, starch concentration was relevant to include in the study.

Finally, since wheat is used to a large extent for baking, some quality traits are related to baking quality. Here the Zeleny value, the Hagberg falling number and gluten are frequently used indicators. The Zeleny value is determined by a sedimentation test that measures the rate of sedimentation of wheat flour suspended in an acid solution. Sedimentation occurs due to swelling of glutenin, which is a major protein in wheat flour. A high Zeleny value (sedimentation volume) is associated with a high protein content and good baking quality (Eckert et al., 1993; Reeves et al., 1978). Hagberg falling number is a measure of $\alpha$-amylase activity in wheat grains and its resistance to enzymatic degradation. Low falling numbers represent high $\alpha$-amylase activity and thus more germinated grains, resulting in poor baking qualities, such as sticky dough and poorly structured loaves (Kindred et al., 2005). Additionally, a higher falling number enables longer storage time for flour and grains (Hruskova et al., 2004).

The aim of this study is to provide a comprehensive overview of all known effects of $\mathrm{O}_{3}$ on wheat grain quality based on all available ecologically realistic experiments, using open-top chambers (OTC) or free air concentration enrichment with ozone (FACE) and presented as meta-analysis (to check the statistical significance of the effects) and as response regressions (to assess the magnitude of effect in relation to exposure).

\section{Materials and methods}

\subsection{Database}

Relevant papers were searched using Web of Science and selected to be included if the following criteria were fulfilled:

1. Daytime ozone concentration, $\left[\mathrm{O}_{3}\right]_{\text {day, }}$ was reported (7-h, 8-h, 12-h, 6-h or 4-h).

2. At least one of the following yield quality responses was reported: 1000-grain weight, volume weight, grain protein concentration, mineral nutrient concentration ( $\mathrm{P}, \mathrm{K}, \mathrm{Ca}, \mathrm{Zn}, \mathrm{Fe}, \mathrm{Mn}$, $\mathrm{Mg}, \mathrm{Cu}, \mathrm{S}, \mathrm{Na}$ ), $\mathrm{Cd}$ concentration, or baking quality properties (Hagberg falling number, Zeleny value, wet and dry gluten concentrations). Grain yield data were also extracted from the data sources to calculate yields of protein and minerals but grain yield as such is not the main focus of the present paper.

3. Ozone exposure was at least 14 days.

4. $\left[\mathrm{O}_{3}\right]_{\text {day }}$ for elevated ozone treatments was at least $30 \mathrm{ppb}$ during exposure.

5. Plants were rooted in field soil, i.e. pot experiments were excluded. 19.

The total number of wheat cultivars included in the study was

After selection, a total of 36 publications were used for this meta-analysis (Appendix 1). Analyses were performed only for variables for which data existed from at least three experiments. Data used, but not available in the open literature, were mineral concentrations (ICP-Mass Spectrometry) for the Gelang et al. (2000) experiment, starch for the Pleijel et al. (1998) experiment and minerals and protein for the Chinese experiment described in Zhu et al. (2011) (minerals, protein 2007-2009 and all quality data for 2010). Data from figures were digitized using data extraction software (Get Data Graph Digitizer 2.26; http://getdata-graphdigitizer.com/).

\subsection{Meta-analysis}

Two parallel meta-analyses were performed for the yield quality variables, one with charcoal filtered air $(\mathrm{CF})$ as control and the other with non-filtered air (NF) as control. Since FACE experiments never included a reduced $\mathrm{O}_{3}$ treatment corresponding to the $\mathrm{CF}$ treatment used in most OTC experiments, FACE experiments could not be included in meta-analyses using $\mathrm{CF}$ as the control. In order to explain variation in yield quality responses, the following categories were included: (1) wheat type (spring vs. winter wheat); (2) fumigation facility (OTC vs. FACE). Parameter values were considered independent if they were made on different cultivars or $\mathrm{O}_{3}$ concentrations, following the approach of previous meta-analyses (Curtis and Wang, 1998; Feng et al., 2008).

The meta-analysis was conducted using a meta-analytical software package (MetaWin2.1.3.4, Sinauer Associates, Inc. Sunderland, MA, USA) (Rosenberg et al., 2000). To estimate the treatment effect, the natural $\log$ of the response ratio $\left(r=\right.$ variable in elevated $\left[\mathrm{O}_{3}\right] /$ variable in control) was used as the metric for analysis (Hedges et al., 1999; Rosenberg et al., 2000) and reported as the percentage changes from control as $(r-1) \times 100 \%$ (Curtis and Wang, 1998; Feng et al., 2008). Negative percentage changes indicate a decrease in the variable in response to elevated $\left[\mathrm{O}_{3}\right]$ treatment, while positive values indicate an increase.

Only a limited part of the papers reported data that would allow computation of sample variance (standard deviations or standard errors with replication). Therefore, all variables were analysed using an un-weighted approach in which the variance of the effect size was calculated using resampling techniques after 59,999 iterations (Adams et al., 1997; Feng et al., 2008; Rosenberg et al., 2000). Confidence limits around the effect size were calculated using a bootstrap method (Rosenberg et al., 2000). Estimates of the effect size were assumed to be significant if the $95 \%$ confidence intervals (CI) did not overlap zero (Curtis and Wang, 1998). The difference between categorical variables was considered significant if the 95\% CIs did not overlap (Curtis and Wang, 1998; Feng et al., 2008).

\subsection{Response functions}

Response functions were derived between the relative effects of $\mathrm{O}_{3}$ in the experiments vs. $\left[\mathrm{O}_{3}\right]_{\text {day. }}$. Effects were related to the effect estimated at zero $\left[\mathrm{O}_{3}\right]_{\text {day }}$ for each experiment. At zero $\left[\mathrm{O}_{3}\right]_{\text {day }}$ exposure, the biological variables were set to take the value of 1 on 
a relative scale, i.e. it was assumed that there was no $\mathrm{O}_{3}$ effect associated with zero $\left[\mathrm{O}_{3}\right]_{\text {day }}$ in each experiment. Although other $\mathrm{O}_{3}$ indices, especially the POD (Phytotoxic Ozone Dose, Grunhage et al., 2011) and AOT40 (Accumulated Exposure over Threshold of $40 \mathrm{ppb}$ hourly $\mathrm{O}_{3}$, Fuhrer et al., 1997), may result in stronger relationships, the $\left[\mathrm{O}_{3}\right]_{\text {day }}$ was preferred in the present study since it is reported for almost all experiments and in this review the priority was to include as much as possible of the data reported for $\mathrm{O}_{3}$ effects on wheat quality. The time-resolved data for calculating AOT40 (ozone concentrations) and POD (ozone concentrations and several meteorological variables) are only available for a very limited number of experiments.

The following limitations were defined for inclusion of data in the response functions:

1. Experimental treatments were excluded if $\left[\mathrm{O}_{3}\right]_{\text {day }}$ was larger than $100 \mathrm{ppb}$, in order to avoid the influence on the regressions from a few very high $\mathrm{O}_{3}$ treatments.

2. Data were also excluded from the response function if they contained only two data points (treatments) in combination with $\mathrm{NF}$ being the control treatment and $\left[\mathrm{O}_{3}\right]_{\text {day }}$ for $\mathrm{NF}$ was larger than $30 \mathrm{ppb}$, to avoid the uncertainty in the determination of the intercept associated with large extrapolation in combination with only two observations.

3. Experiments with an $\left[\mathrm{O}_{3}\right]_{\text {day }}$ range (difference between highest and lowest $\mathrm{O}_{3}$ treatment) smaller than $15 \mathrm{ppb}$ were excluded since random effects become large in relation to the difference in exposure for such experiments.
In order to correct for different time intervals (the number of daytime hours included in the average) in $\left[\mathrm{O}_{3}\right]_{\text {day }}$ measurements, a daily average for 40 European monitoring stations was calculated for the time period May to July for each time interval (4-h, 6-h, 7-h, 8-h, and 12-h). $\mathrm{O}_{3}$ data were retrieved from The European Monitoring and Evaluation Programme (EMEP, www.emep.int). $\left[\mathrm{O}_{3}\right]_{7-\mathrm{h}}$ was the most frequently occurring measurement interval for the selected experiments and chosen as a standard. The average $\left[\mathrm{O}_{3}\right]_{12-}$ $\mathrm{h}$ for EMEP measurements was about $4.1 \%$ lower than the 7-h standard and therefore all $\left[\mathrm{O}_{3}\right]_{12-\mathrm{h}}$ were adjusted to $\left[\mathrm{O}_{3}\right]_{7-\mathrm{h}}$ with a conversion factor of 1.041. However, the average $\left[\mathrm{O}_{3}\right]_{4-\mathrm{h}},\left[\mathrm{O}_{3}\right]_{6-\mathrm{h}}$ and $\left[\mathrm{O}_{3}\right]_{8 \text {-h }}$ were estimated to differ less than $1 \%$ from the 7 -h standard and were consequently not corrected.

All regression response functions, including that for GY, are presented with respect to number of experiments, number of experimental treatments, countries and continents contributing data to the analysis, coefficient of determination $\left(R^{2}\right)$, statistical significance, intercept and slope in Table 1. A small selection of the response regression is shown as figures in the Results section.

\section{Results}

\subsection{Grain yield, 1000-grain weight and volume weight}

In Figs. 1 and 2, the effects of $\mathrm{O}_{3}$ on grain yield (GY), 1000-grain weight and volume weight are presented using the CF treatment and the NF treatment as the reference, respectively. Except for volume weight using $\mathrm{CF}$ as the reference (Fig. 1) all variables were significantly negatively affected by $\mathrm{O}_{3}$. For GY and 1000-grain

Table 1

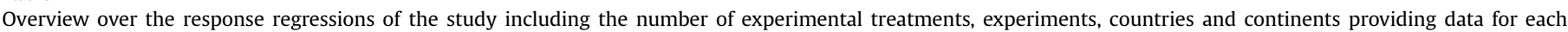

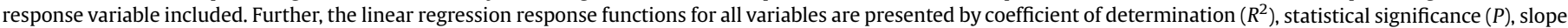
(represented by the \% effect per $10 \mathrm{ppb} \mathrm{O}_{3}$ ) and the intercept.

\begin{tabular}{|c|c|c|c|c|c|c|c|c|c|c|}
\hline \multicolumn{2}{|l|}{ Variable } & Treatments & Experiments & Countries & Continents & $R^{2}$ & $P$ & & $\%$ Effect per $10 \mathrm{ppb}$ & Intercept \\
\hline \multicolumn{2}{|c|}{ Grain yield } & 115 & 35 & 9 & 3 & 0.513 & $<0.001$ & $* * *$ & -4.7 & 1.00 \\
\hline \multicolumn{2}{|c|}{ 1000-Grain weight } & 107 & 33 & 9 & 3 & 0.532 & $<0.001$ & $* * *$ & -3.9 & 1.01 \\
\hline \multicolumn{2}{|c|}{ Grain number } & 77 & 21 & 6 & 3 & 0.062 & $<0.05$ & $*$ & -1.0 & 0.97 \\
\hline \multicolumn{2}{|c|}{ Volume weight } & 23 & 9 & 3 & 2 & 0.354 & $<0.01$ & $* *$ & -1.1 & 1.01 \\
\hline \multirow[t]{2}{*}{ Protein } & Concentration & 69 & 22 & 6 & 3 & 0.399 & $<0.001$ & $* * *$ & 2.6 & 1.00 \\
\hline & Yield & 69 & 22 & 6 & 3 & 0.503 & $<0.001$ & $* * *$ & -4.1 & 1.02 \\
\hline \multirow[t]{2}{*}{$\mathrm{Zn}$} & Concentration & 17 & 5 & 2 & 2 & 0.803 & $<0.001$ & $* * *$ & 3.3 & 1.01 \\
\hline & Yield & 17 & 5 & 2 & 2 & 0.203 & 0.070 & ns & -2.4 & 0.97 \\
\hline \multirow[t]{2}{*}{$\mathrm{Mn}$} & Concentration & 19 & 6 & 3 & 2 & 0.204 & 0.052 & ns & 8.0 & 0.93 \\
\hline & Yield & 19 & 6 & 3 & 2 & 0.000 & 0.985 & ns & 0.0 & 0.94 \\
\hline \multirow[t]{2}{*}{ Cd } & Concentration & 17 & 5 & 1 & 1 & 0.107 & 0.200 & ns & -1.5 & 1.00 \\
\hline & Yield & 17 & 5 & 1 & 1 & 0.487 & $<0.01$ & $* *$ & -5.5 & 0.97 \\
\hline \multirow[t]{2}{*}{ K } & Concentration & 33 & 10 & 4 & 2 & 0.440 & $<0.001$ & $* * *$ & 3.6 & 0.94 \\
\hline & Yield & 33 & 10 & 4 & 2 & 0.647 & $<0.001$ & $* * *$ & -4.9 & 0.98 \\
\hline \multirow{2}{*}{$\mathrm{Ca}$} & Concentration & 25 & 8 & 4 & 2 & 0.497 & $<0.001$ & $* * *$ & 4.4 & 0.92 \\
\hline & Yield & 25 & 8 & 4 & 2 & 0.680 & $<0.001$ & $* * *$ & -5.2 & 0.98 \\
\hline \multirow[t]{2}{*}{$\mathrm{Mg}$} & Concentration & 25 & 8 & 4 & 2 & 0.633 & $<0.001$ & $* * *$ & 5.3 & 0.93 \\
\hline & Yield & 25 & 8 & 4 & 2 & 0.574 & $<0.001$ & $* * *$ & -4.9 & 0.99 \\
\hline \multirow[t]{2}{*}{$\mathrm{Na}$} & Concentration & 11 & 3 & 3 & 2 & 0.005 & 0.837 & ns & -0.9 & 0.86 \\
\hline & Yield & 11 & 3 & 3 & 2 & 0.199 & 0.170 & ns & -5.4 & 0.89 \\
\hline \multirow[t]{2}{*}{$\mathrm{P}$} & Concentration & 25 & 8 & 4 & 2 & 0.620 & $<0.001$ & $* * *$ & 4.4 & 0.94 \\
\hline & Yield & 25 & 8 & 4 & 2 & 0.619 & $<0.001$ & $* * *$ & -5.1 & 0.99 \\
\hline \multirow[t]{2}{*}{$\mathrm{Fe}$} & Concentration & 9 & 2 & 2 & 2 & 0.565 & $<0.05$ & * & 2.9 & 0.97 \\
\hline & Yield & 9 & 2 & 2 & 2 & 0.230 & 0.191 & ns & -3.3 & 0.91 \\
\hline \multirow[t]{2}{*}{$\mathrm{Cu}$} & Concentration & 9 & 2 & 2 & 2 & 0.299 & 0.128 & ns & 4.8 & 0.92 \\
\hline & Yield & 9 & 2 & 2 & 2 & 0.042 & 0.599 & ns & -1.8 & 0.90 \\
\hline \multirow[t]{2}{*}{$S$} & Concentration & 11 & 3 & 3 & 2 & 0.179 & 0.195 & ns & 1.3 & 0.97 \\
\hline & Yield & 11 & 3 & 3 & 2 & 0.397 & $<0.05$ & * & -4.3 & 0.96 \\
\hline \multicolumn{2}{|c|}{ Starch concentration } & 29 & 9 & 3 & 1 & 0.410 & $<0.001$ & $* * *$ & -1.6 & 1.02 \\
\hline \multicolumn{2}{|c|}{ Hagberg falling number } & 14 & 6 & 2 & 1 & 0.309 & $<0.05$ & * & 2.9 & 1.03 \\
\hline \multicolumn{2}{|c|}{ Zeleny value } & 16 & 6 & 2 & 1 & 0.717 & $<0.001$ & $* * *$ & 3.8 & 1.00 \\
\hline \multicolumn{2}{|c|}{ Dry gluten } & 8 & 4 & 1 & 1 & 0.465 & 0.062 & ns & 3.0 & 1.00 \\
\hline \multicolumn{2}{|c|}{ Wet gluten } & 8 & 4 & 1 & 1 & 0.439 & 0.073 & ns & 2.8 & 1.01 \\
\hline
\end{tabular}




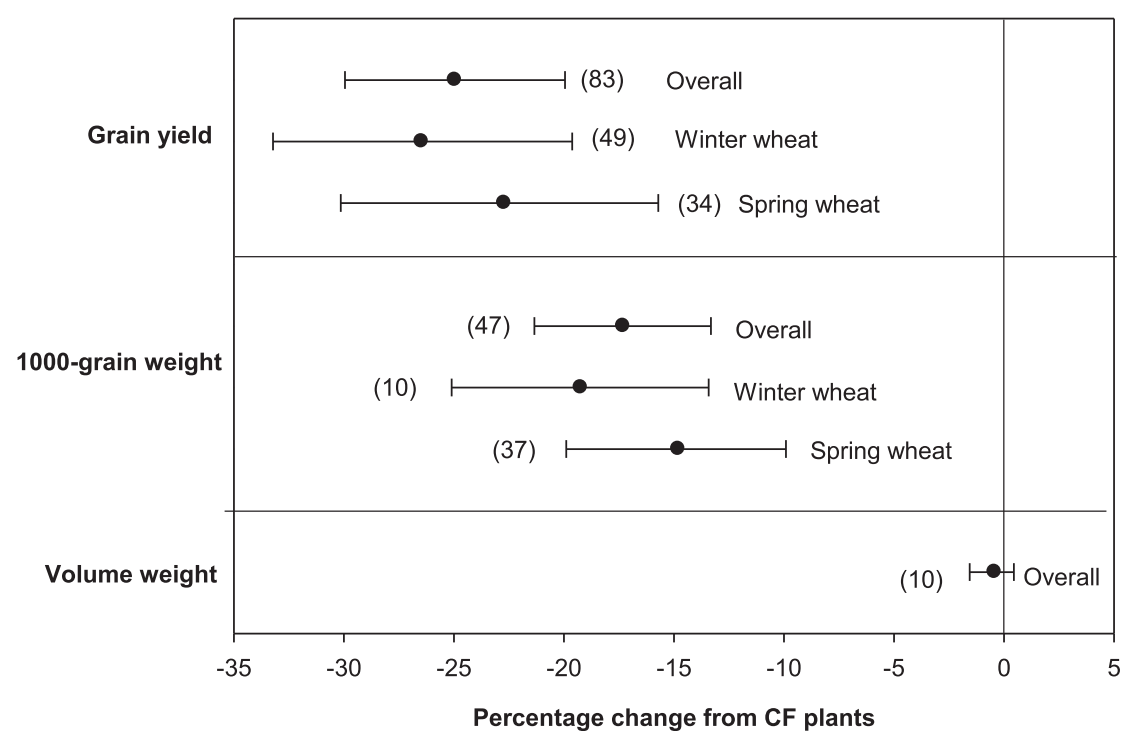

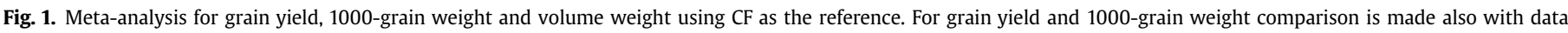
separated for spring wheat and winter. Numbers within brackets represent the number of comparisons included in the meta-analysis for each variable.

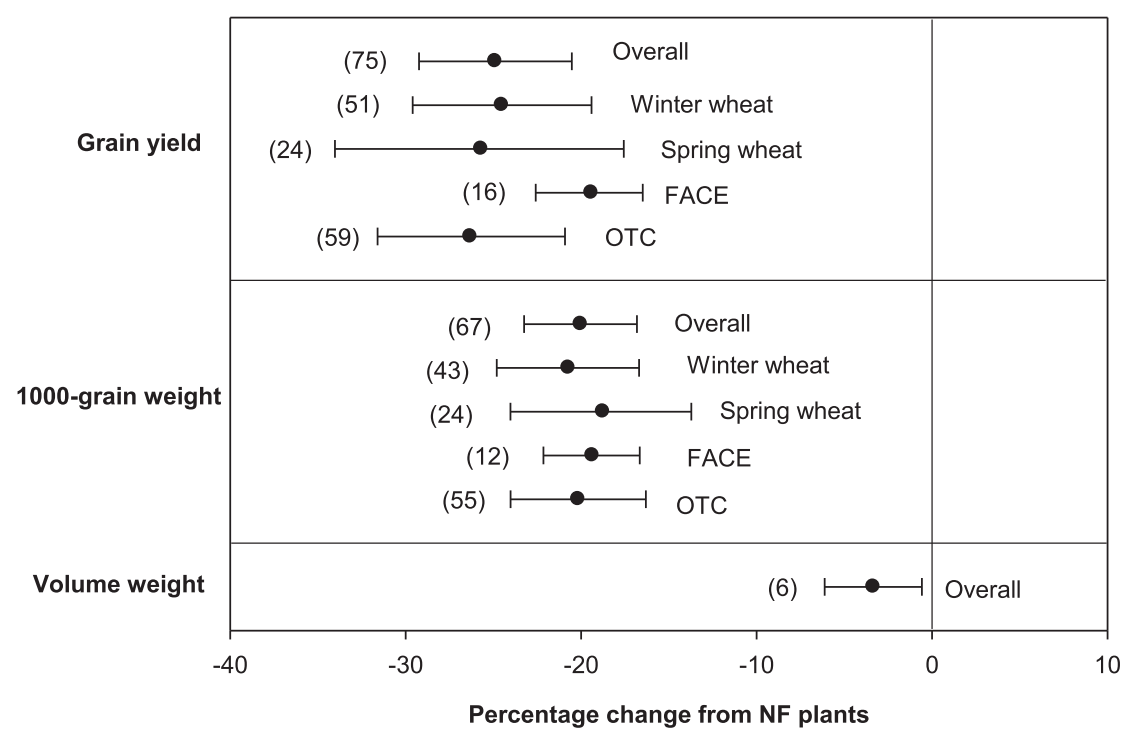

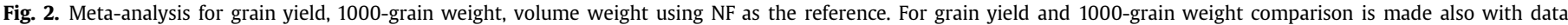

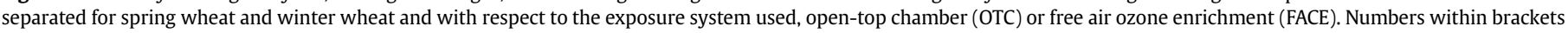
represent the number of comparisons included in the meta-analysis for each variable.

weight there were strongly significant negative effects, which differed relatively little between spring and winter wheat. The comparison of effects in OTC experiments and FACE experiments (Fig. 2) suggested no statistically significant differences. For 1000grain weight the difference was very small, whereas a larger but non-significant difference was noted for GY with larger effects in OTCs than FACE.

The regression response function for volume weight is displayed as Fig. 3. The negative effect by $\mathrm{O}_{3}$ on this quality trait was comparatively small, and reported in a limited number of experiments, but resulted in a statistically significant regression response function. The response function for 1000-grain weight had a stronger negative slope (Table 1 ). In fact, as obvious from Fig. 4, which exhibits the effects of $\mathrm{O}_{3}$ on GY plotted vs. the corresponding effects on 1000-grain weight, the negative effects of $\mathrm{O}_{3}$ on GY in wheat is dominated by effects on 1000-grain weight, leaving the negative effect of $\mathrm{O}_{3}$ on grain number (Table 1 ) a minor factor.

\subsection{Protein and starch}

Grain protein concentration (GPC) was significantly positively affected by $\mathrm{O}_{3}$, while grain protein yield (GPY) was significantly negatively affected (Figs. 5 and 6). Results for spring and winter wheat, as well as for OTC compared to FACE experiments, did not suggest significant differences between groups. Starch concentration was negatively affected with the exception of spring wheat (non-significant with small margin) using NF as the reference treatment (Fig. 6).

Fig. 7a shows the response regression for GPC, exhibiting a consistent positive response. In Fig. $7 \mathrm{~b}$ the significant negative response regression for grain starch concentration is presented. 


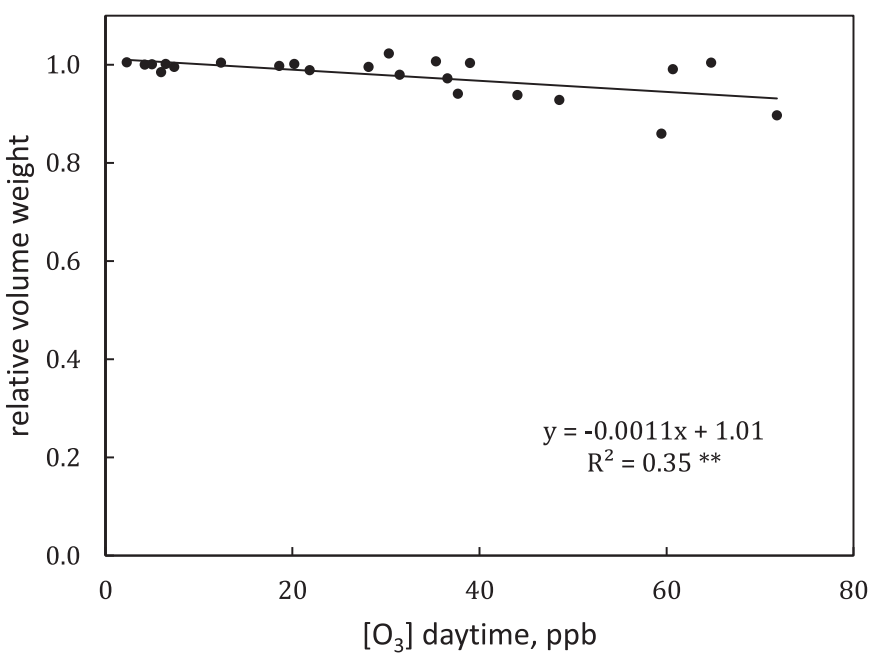

Fig. 3. Regression response functions between volume weight with average daytime 7-h ozone concentration.

\subsection{Concentration and yield of minerals}

Generally, fewer experiments have reported data on grain mineral content as compared to 1000-grain weight and grain protein. However, there is substantial evidence to conclude that for the important nutrients $\mathrm{Mg}, \mathrm{Ca}, \mathrm{K}, \mathrm{P}, \mathrm{Zn}, \mathrm{Mn}$ there was a significant positive effect by $\mathrm{O}_{3}$ on the concentration but a significant negative one on the yield when CF (Fig. 8) was used as the reference. For Zn and $\mathrm{Mn}$ the effect on concentration was not statistically significant when using NF as the reference (Fig. 9). For P, K, Mg, Ca and $\mathrm{Cu}$ both the effects on concentration and yield were statistically significant when using NF as the reference (Fig. 9). In the case of especially Na

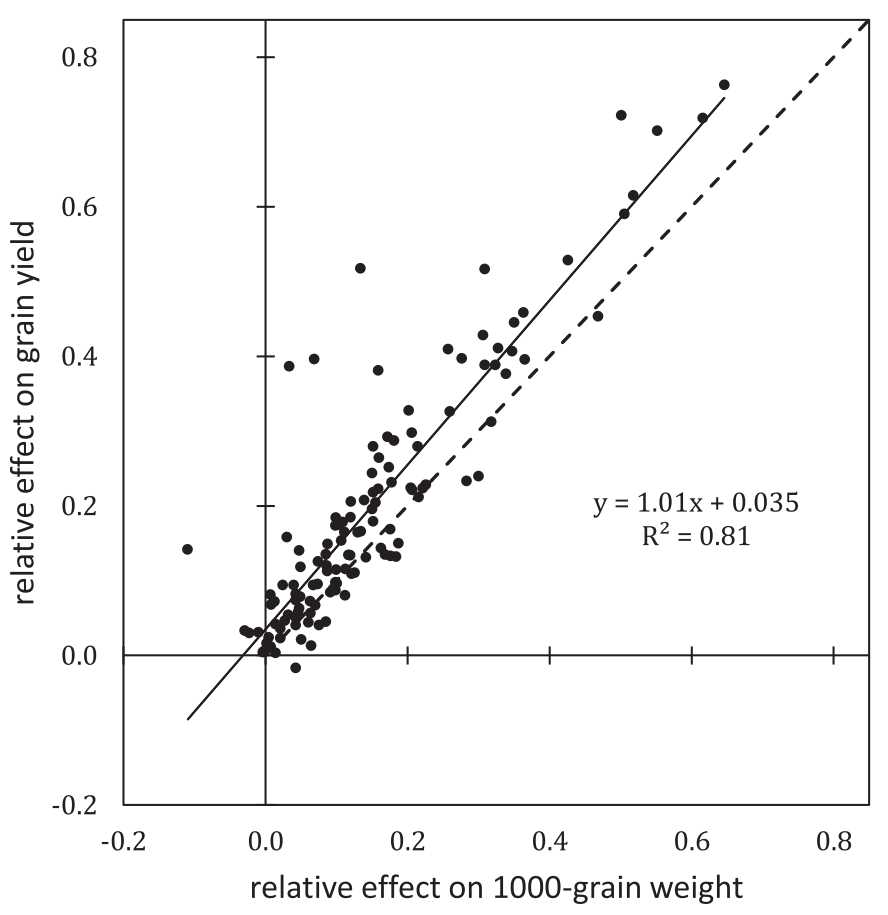

Fig. 4. Ozone effect on grain yield vs. the corresponding effect on 1000-grain weight obtained in the regression analysis. The broken line represents the theoretical situation where the effects of $\mathrm{O}_{3}$ on grain yield are entirely explained by effects on 1000-grain weight. and Fe the variability in the response was large and no firm conclusions can be drawn with the respect to the $\mathrm{O}_{3}$ effects on these elements. For the potentially toxic, non-essential element $\mathrm{Cd}$, and unlike all the nutrient elements, there was a significant negative effect of $\mathrm{O}_{3}$ both on concentration and yield, regardless if $\mathrm{CF}$ or NF was used as the reference for the meta-analysis (Figs. 8 and 9). It should be noted that the highest levels of grain $\mathrm{Cd}$ in the experiments included were in the range of $55-60 \mu \mathrm{g} \mathrm{kg}-1$ (data not shown), which is below e.g. the limit value for Cd concentrations of wheat grain of the EU (EC Regulation No 1881/2006): $200 \mu \mathrm{g} \mathrm{kg}^{-1}$. However, both concentration and total intake are important for the dose and cereal products are indeed a major contributor to dietary cadmium exposure (EFSA, 2009). For the element $S$ the effect on concentration was not statistically significant, neither using $C F$, nor using NF as the reference.

As a representative example, the $P$ grain concentration and yield responses to $\mathrm{O}_{3}$ are presented as response functions in Fig. 10. All four macronutrients, and with somewhat smaller effects also the micronutrient $\mathrm{Zn}$, had similar responses with substantial and statistically significant positive $\mathrm{O}_{3}$ response regression for concentration and approximately equally strong and significant negative effects for yields (Table 1). These effects were of the same magnitude for the four macronutrient minerals.

\subsection{Baking properties}

Baking properties were reported in rather few experiments, some of which were limited to CF-NF comparison. Thus, metaanalysis was only made with $\mathrm{CF}$ as reference. All four studied variables, Zeleny value, Hagberg falling number and dry and wet gluten content, were positively affected by $\mathrm{O}_{3}$ (Fig. 11). The response regression for Zeleny value shown in Fig. 12 is positive and statistically significant. It is stronger and based on a slightly larger number of data points than the similar positive relationship for Hagberg falling number (Table 1).

\section{Discussion}

The qualitative review by Wang and Frei (2011) clearly showed that $\mathrm{O}_{3}$ has a strong potential to affect a wide range of quality traits in crops and that both negative and positive effects are likely to occur. Indeed, the comprehensive quantitative assessment of the present study shows that $\mathrm{O}_{3}$ has a wide range of significant effects on wheat quality and that some of the effects can be regarded as negative, while other are positive. Among the unequivocally adverse effects are the strong negative influence on 1000-grain weight and the smaller but significant effect on volume weight, both indicating a larger number of very small and/or malformed kernels are formed under $\mathrm{O}_{3}$ exposure. The significant negative effect of $\mathrm{O}_{3}$ on starch concentration is consistent with this, since for small/malformed kernels the fraction of starch is likely to be reduced. Wang and Frei (2011) found a negative effect of $\mathrm{O}_{3}$ on starch concentrations in some crops, but not in cereals. However, they suggest that environmental stresses, such as $\mathrm{O}_{3}$, could act to inhibit key enzymes for starch synthesis, causing hampered conversion of sugar to starch. Here, we show a strong negative relationship of starch concentrations with $\mathrm{O}_{3}$ based on larger database for wheat.

It is obvious that the effect of $\mathrm{O}_{3}$ on wheat grain is to reduce the average 1000-grain weight and only to a much smaller extent the grain number, as was also observed in some earlier studies (e.g. Pleijel and Uddling, 2012). This observation is in line with the general post-anthesis senescence-promoting effect of $\mathrm{O}_{3}$ (Grandjean and Fuhrer, 1989), which shortens the period of grain growth (Gelang et al., 2000). The reduction in 1000-grain weight is 


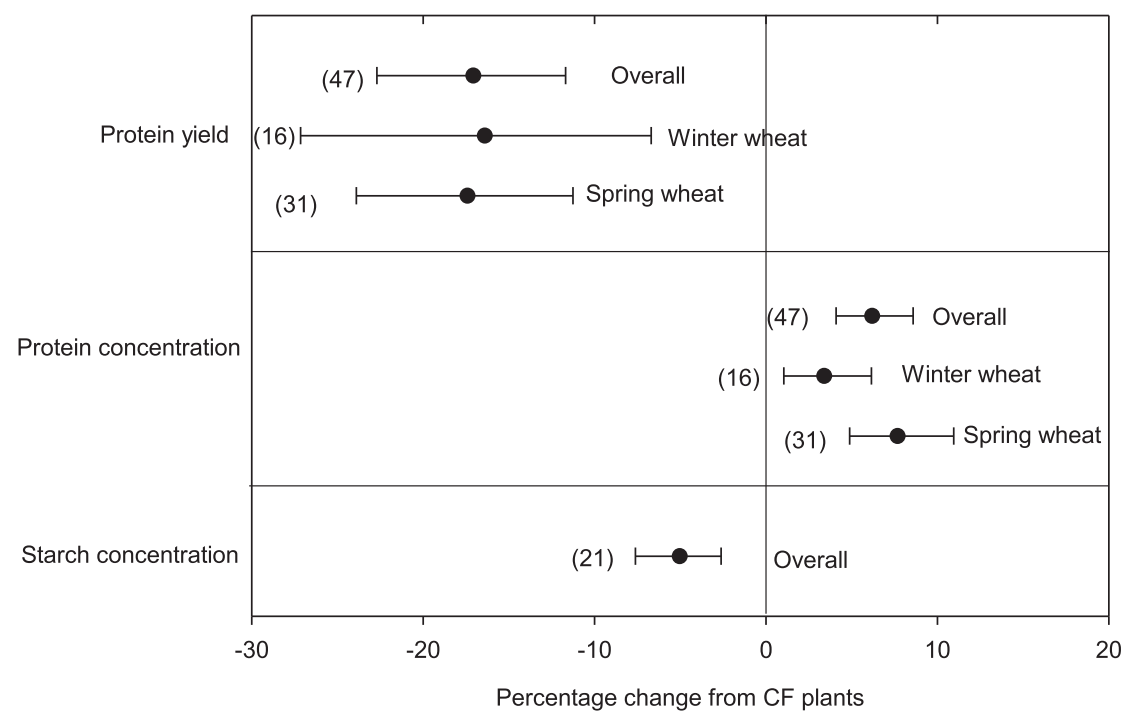

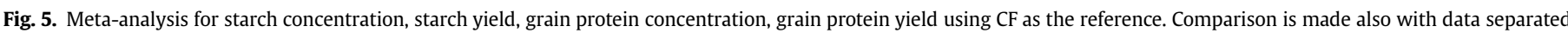
for spring wheat and winter wheat. Numbers within brackets represent the number of comparisons included in the meta-analysis for each variable.

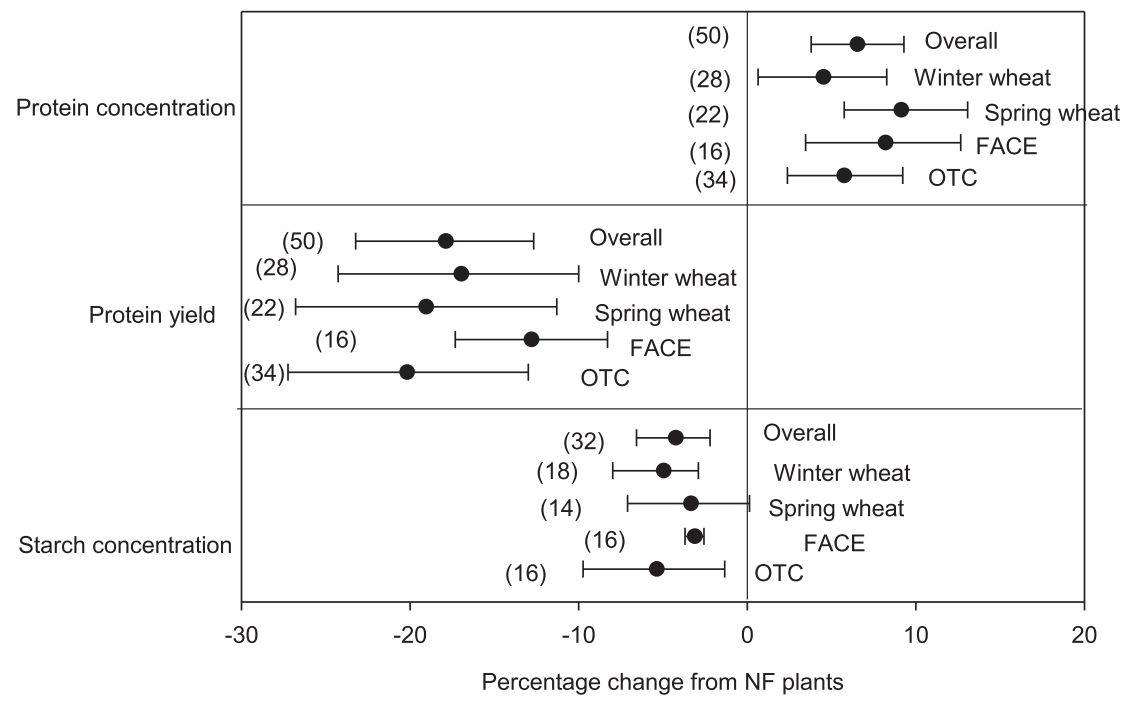

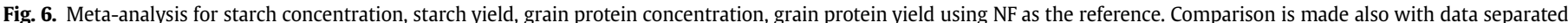

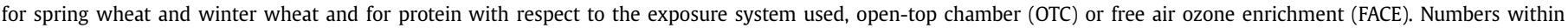
brackets represent the number of comparisons included in the meta-analysis for each variable.

a logical consequence of the shortened grain filling period in combination with a lower $\mathrm{O}_{3}$ sensitivity during earlier stages of plant growth (Soja et al., 2000) when the number of grain initials is largely determined.

Among $\mathrm{O}_{3}$ effects that were positive can be mentioned the negative effect on both $\mathrm{Cd}$ concentration and $\mathrm{Cd}$ yield, as well as the positive effects on baking properties. The concentration and quality (Zeleny value) of gluten protein were positively influenced. The same was true for the Hagberg falling number reflecting lower $\alpha$ amylase activity. Several factors may contribute to this pattern, including the general increase in grain protein concentration, but also the early or premature ripening of the grain under elevated $\mathrm{O}_{3}$. For example, a late ripening often leads to a high $\alpha$-amylase activity in the grain, lowering the quality and in worst case (under humid conditions) promoting germination of the grains before harvest (Lunn et al., 2001). In the case of the non-essential element $\mathrm{Cd}$, the uptake and transport is known to depend on transpiration (Salt et al., 1995). $\mathrm{O}_{3}$ is known to reduce both the stomatal conductance and the leaf life span (Mulholland et al., 1997), which can explain the observed pattern for Cd. Fig. 8, using CF as the reference, indicates that the two non-essential elements included, $\mathrm{Cd}$ and $\mathrm{Na}$, had a similar response with reduced concentrations under elevated $\mathrm{O}_{3}$, in contrast to all the essential elements for which the concentrations enhanced. This points towards a general pattern with respect to the different physiological mechanisms governing the uptake of essential and non-essential elements, where the passive transport with the transpiration stream through the plant is a strong feature for non-essential elements, while specific uptake mechanisms play the important role for the essential elements. However, in the case of $\mathrm{Na}$, but not $\mathrm{Cd}$, the pattern was different when using NF as the basis for comparison (Fig. 9). It should be noted that both in the case of $\mathrm{Cd}$ and the different aspects of baking quality, the amount of data available was relatively small and only represented by experiments performed in Europe. 

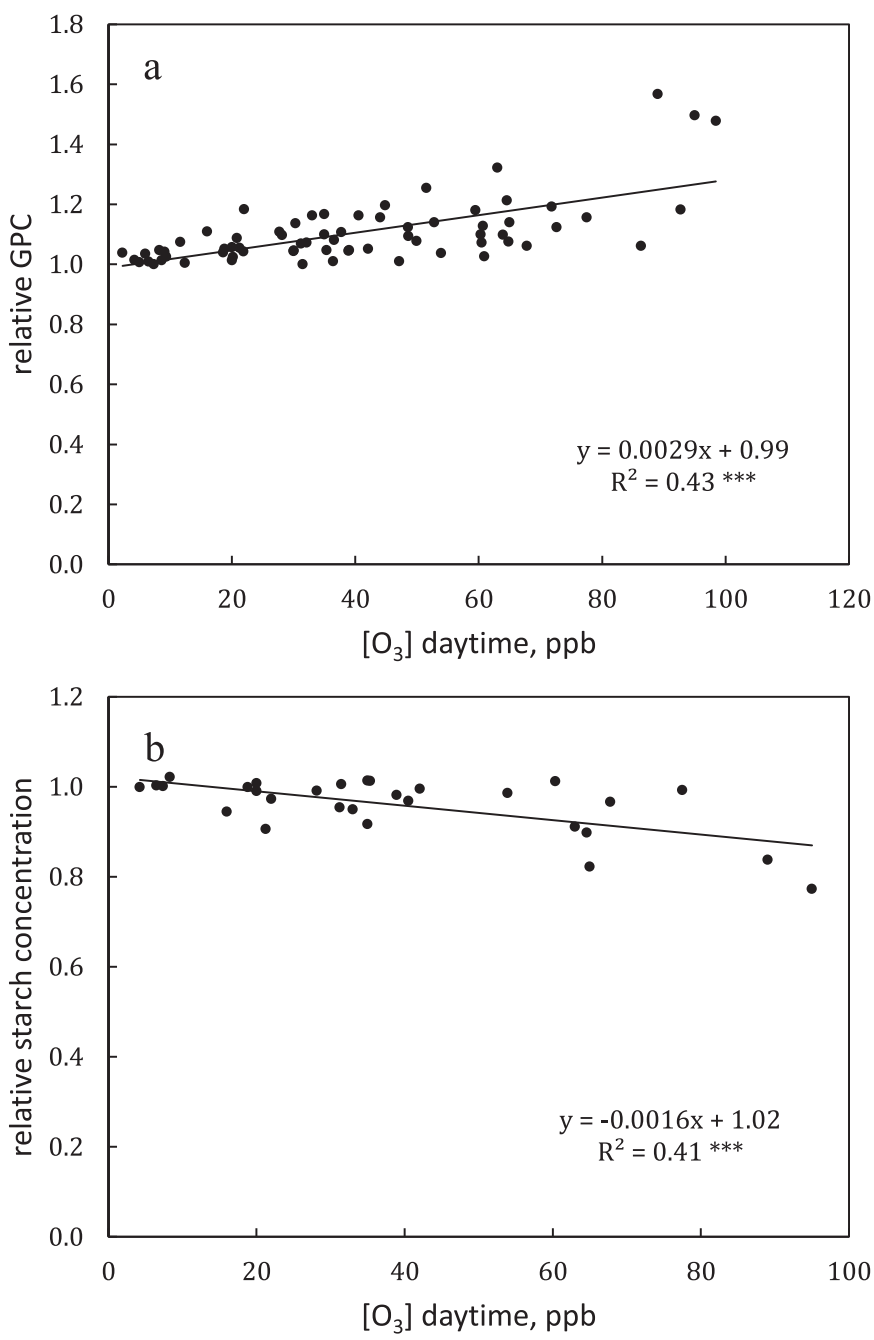

Fig. 7. Response functions for a) grain protein concentration (GPC), b) grain starch concentration, with average daytime ozone concentration.

In the case of grain protein and most of the important minerals (especially Mg, P, Ca, K, Mn and Zn) it can be noted that a consistent pattern was observed with a significant positive effect on concentration and an approximately equally strong negative effect on the yield using $\mathrm{CF}$ as the basis for comparison. This means that the quality of the grain is improved with respect to concentration, but the amount of protein and minerals accumulated per unit area is reduced, which may have serious effects on human nutrition. Further, this shows that a smaller amount of nitrogen and the mentioned minerals was taken up from the soil. Our findings are consistent with what was observed in some individual studies, e.g. of Ca, Mg, K, and P by Fuhrer et al. (1990), K and P by Vandermeiren et al. (1992), K and Ca by Feng et al. (2008); and Mg, P, and K by Pleijel et al. (2006), but the consistency of the combined results from many studies is striking and has not been shown before.

Several factors may contribute to the observed pattern of reduced yield and increased concentration of nitrogen and several essential minerals under ozone exposure. The duration of plant growth in annual crops is reduced by ozone (Grandjean and Fuhrer, 1989). Thus, the period of nutrient uptake from the soil is shortened. Additionally, there is evidence that the root-to-shoot ratio is negatively affected by ozone (Cooley and Manning, 1987). As photosynthesis is reduced by ozone stress (Mulholland et al., 1997), so are photosynthates available for root growth, disproportionally

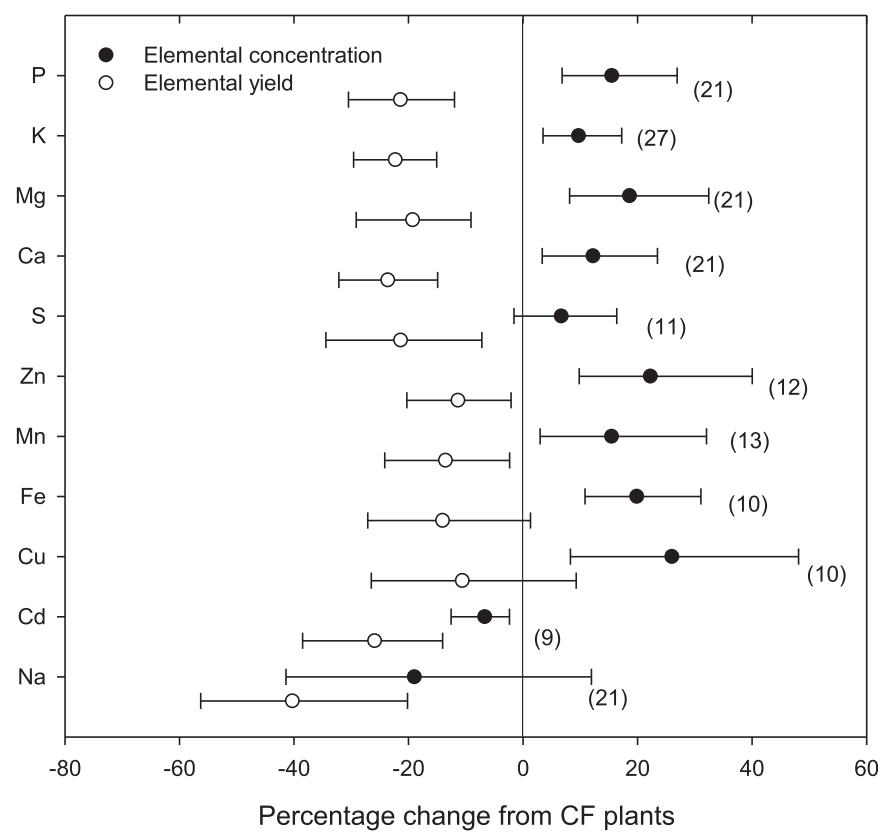

Fig. 8. Meta-analysis for mineral concentration and yield: plant macronutrients $P, K$, $\mathrm{Mg}, \mathrm{Ca}, \mathrm{S}$, plant micronutrients $\mathrm{Zn}, \mathrm{Mn}, \mathrm{Fe}, \mathrm{Cu}$, elements non-essential to plants $\mathrm{Cd}, \mathrm{Na}$, using $\mathrm{CF}$ as the reference. Numbers within brackets represent the number of comparisons included in the meta-analysis for each variable.

affecting the roots. Further, plant growth rate is smaller under elevated ozone. This will tend to reduce nutrient uptake also in the absence of partitioning effects. All these factors promote a reduction of the uptake and yield of nitrogen and mineral nutrients. At the same time it is well known from general crop physiology (Kibite and Evans, 1984) that there is a general anti-correlation between crop yield and nitrogen (protein) concentration, since the uptake of

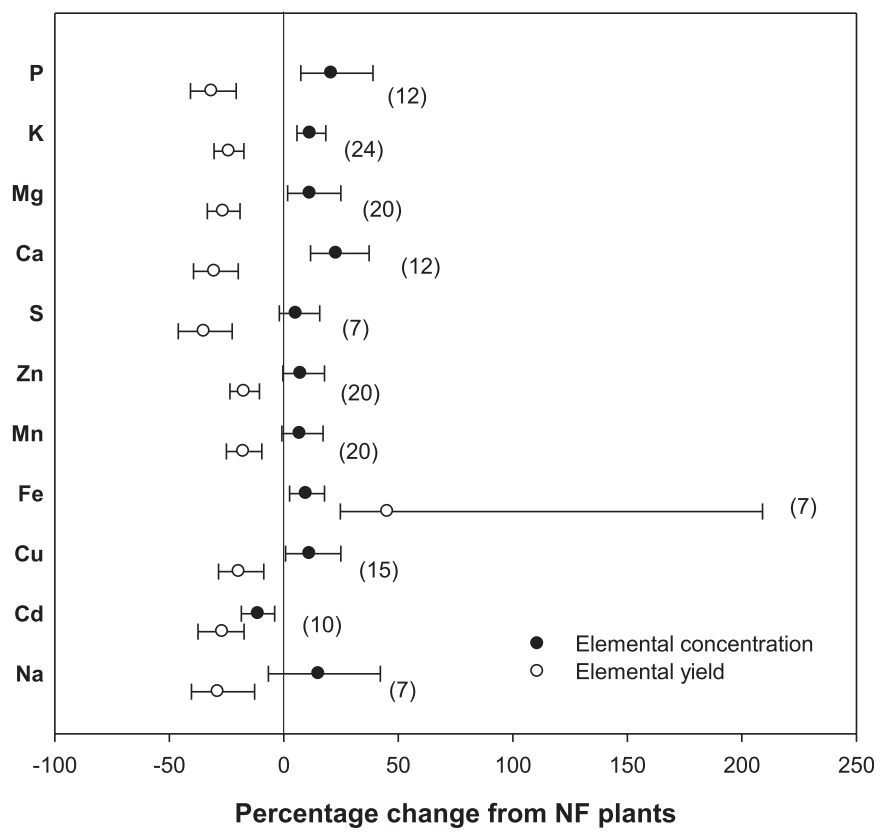

Fig. 9. Meta-analysis for mineral concentration and yield: plant macronutrients $P, K$, $\mathrm{Mg}, \mathrm{Ca}, \mathrm{S}$, plant micronutrients $\mathrm{Zn}, \mathrm{Mn}, \mathrm{Fe}, \mathrm{Cu}$, elements non-essential to plants $\mathrm{Cd}, \mathrm{Na}$, using NF as the reference. Numbers within brackets represent the number of comparisons included in the meta-analysis for each variable. 

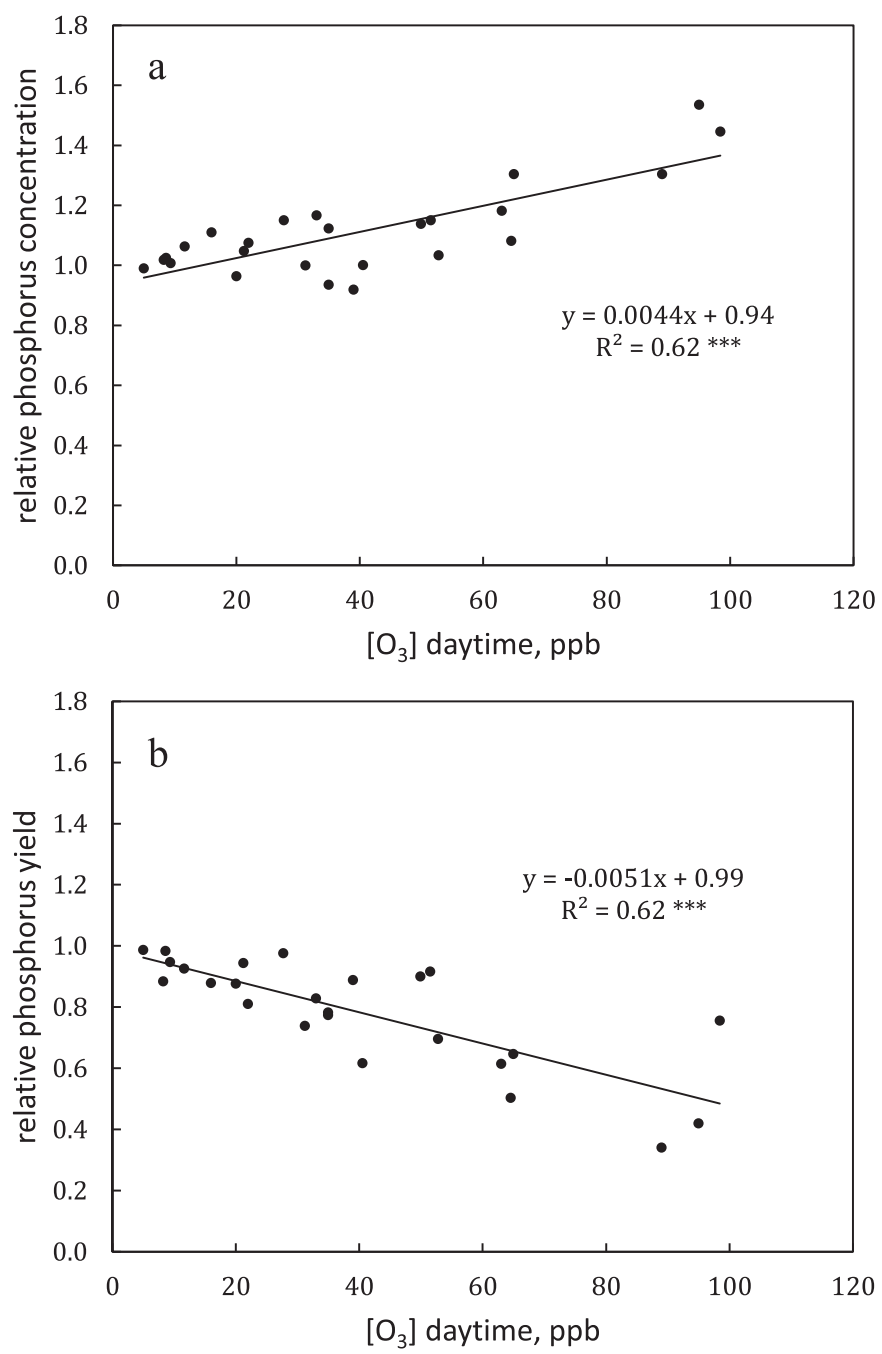

Fig. 10. Response functions for phosphorus a) concentration, and b) yield with average daytime ozone concentration.

nitrogen of crops is in most cases strongly source limited. Thus, crops under stress, e.g. by ozone, will maintain nitrogen uptake, although reduced, to a larger extent than biomass accumulation (Wang and Frei, 2011). The net result is an enhanced protein concentration. From the result of the present study, a similar principle

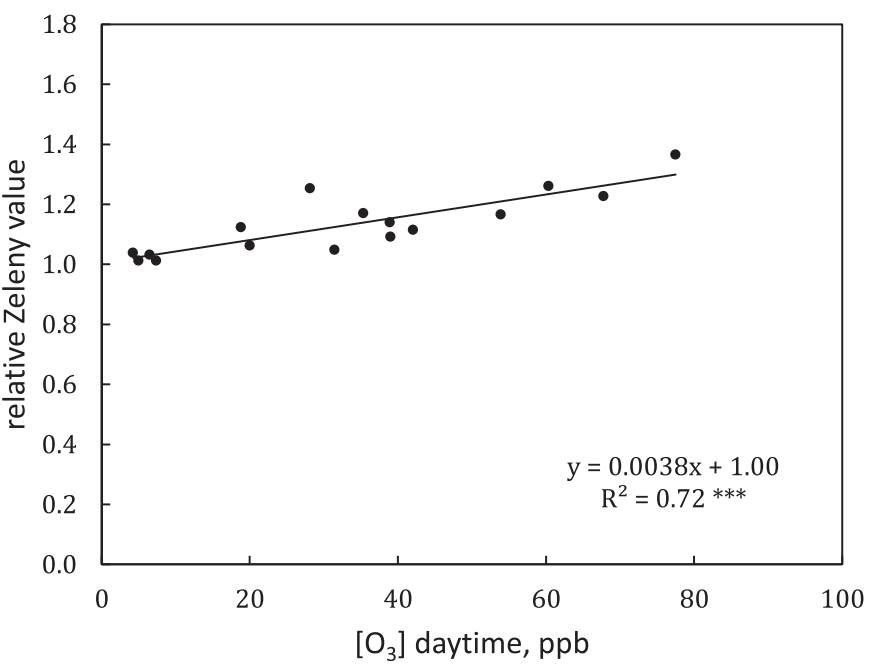

Fig. 12. Response functions for Zeleny value with average daytime ozone concentration.

seems to apply also for other essential elements.

For almost all variables for which a comparison was possible, the effects of $\mathrm{O}_{3}$ were similar for spring and winter wheat. This suggests that the main two groups of wheat varieties behave in a similar way with respect to the sensitivity to $\mathrm{O}_{3}$. Similarly, for the variables permitting comparison, the effects were of the same magnitude and did not differ significantly when comparing OTC and FACE exposure systems. OTC exposed plants tended to exhibit stronger responses to $\mathrm{O}_{3}$, although it was not statistically significant in any single case. It has to be kept in mind also that the OTC experiments included some treatments with rather large elevation $\mathrm{O}_{3}$, while the $\mathrm{O}_{3}$ enhancement in the FACE experiments was modest (Zhu et al., 2011).

In the present analysis we did not attempt to separate the $\mathrm{O}_{3}$ sensitivity of different wheat cultivars other than the comparison of spring and winter wheat. Since each cultivar was mostly used in one or just a few experiments, and there are important differences in agro-environmental conditions in different experimental sites, the comparison of cultivars does not lend itself to the kind of metaanalysis performed here. However, there are examples of experiments where different cultivars were compared in the same experiments, excluding influence of environmental conditions, showing differences in yield magnitude and quality when comparing old and modern cultivars (Pleijel et al., 2006) and when

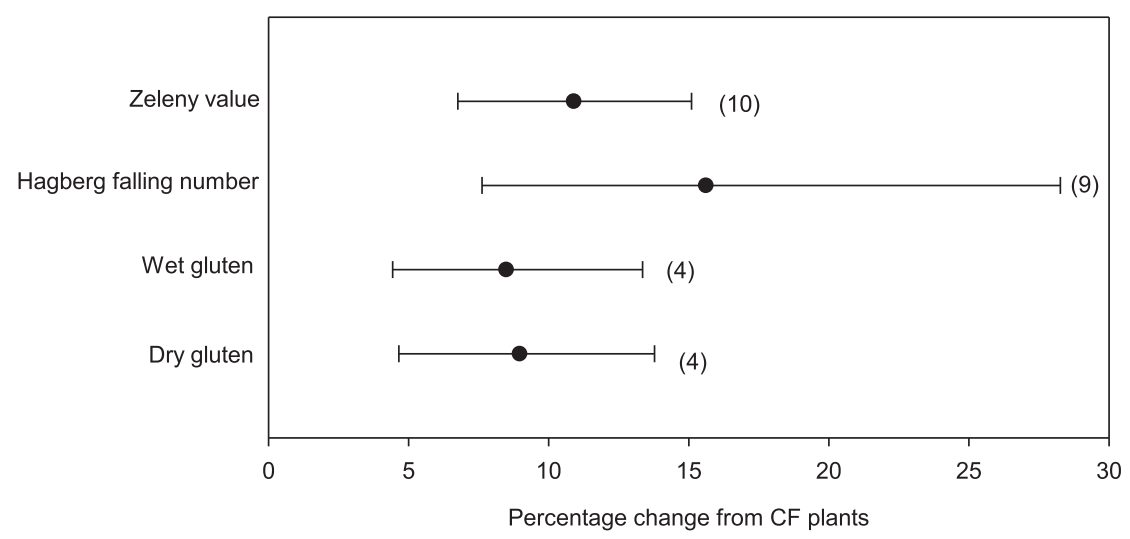

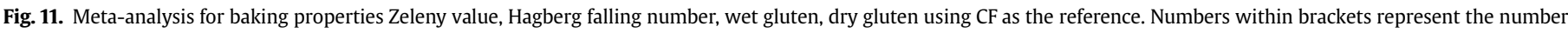
of comparisons included in the meta-analysis for each variable. 
comparing different modern cultivars (Sarkar and Agrawal, 2010). The fact that correlations of response functions were in any cases high, and confidence intervals of meta-analyses small, in the present investigation indicates that the response of many wheat quality variables to $\mathrm{O}_{3}$ is relatively consistent over the range of 19 cultivars included in the present study. Nevertheless the study of cultivar differences in $\mathrm{O}_{3}$ sensitivity is an important matter (Avnery et al., 2013), which deserves further study as part of the strategy to avoid crop loss from $\mathrm{O}_{3}$. These analyses should include both yield magnitude and quality.

Recently Tai et al. (2014) quantified the threat to global food security from $\mathrm{O}_{3}$ pollution in a climate change context, where their modelling suggested significant effects for yields on four major food crops including wheat. In order to obtain a comprehensive picture of the threats by $\mathrm{O}_{3}$ to food security/safety a number of important quality effects have to be added, such as reduced 1000grain weight and volume weight as well as the reduced yields of protein and important minerals. Further assessments of the $\mathrm{O}_{3}$ pressure on global agriculture should include quality and nutritional aspects with direct consideration of the potential for adverse health effects and malnutrition associated with reduced yields of protein and a range of important minerals. As far as possible, they should also cover interactions with other aspects of global change that might have strong effects on agriculture such as elevated $\mathrm{CO}_{2}$, rising temperatures and changes in water availability (Challinor et al., 2009; Lobell and Gourdji, 2012).

\section{Conclusions}

The main conclusions for this study were:

- Ozone significantly reduces 1000 -grain weight (strongly), volume weight and starch concentration of wheat.

- Ozone enhances the concentrations but strongly reduces the yield of important wheat grain constituents such as protein, phosphorus, magnesium, potassium, calcium, zinc and manganese.

- Ozone negatively affected the concentration and yield of the potentially toxic element cadmium.

- Ozone positively affects the baking properties of wheat, as a result of enhanced protein concentration and possibly also the ozone promoted premature senescence.

- Future assessments of $\mathrm{O}_{3}$ effects on global agronomy should include quality and nutritional aspects as well as interactions with $\mathrm{CO}_{2}$ and climate change.

\section{Acknowledgements}

The authors wish to thank the Strategic Research Area BECC (Biodiversity and Ecosystem Services in a Changing Climate, http:// www.cec.lu.se/o.o.i.s/24960), the EU FP7 programme ECLAIRE (Project No. 282910) and the Hundred Talents Program, Chinese Academy of Sciences.

\section{Appendix 1. References used for extraction of original data}

De Temmerman, L., Vandermeiren, K., Guns, M., 1992. Effects of air filtration on spring wheat grown in open-top field chambers at a rural site. 1. Effect on growth, yield and dry-matter partitioning. Environ. Pollut. 77, 1-5.

Fangmeier, A., De Temmerman, L., Mortensen, L., Kemp, K., Burke, J., Mitchell, R., van Oijen, M., Weigel, H.J., 1999. Effects on nutrients and on grain quality in spring wheat crops grown under elevated $\mathrm{CO}_{2}$ concentrations and stress conditions in the
European, multiple-site experiment 'ESPACE-wheat'. Eur. J. Agron. 10, 215-229.

Feng, Z.Z., Yao, F.F., Chen, Z., Wang, X.K., Meng, Q.W., Feng, Z.W., 2007. Response of gas exchange and yield components of fieldgrown Triticum aestivum L. to elevated ozone in China. Photosynthetica $45,441-446$.

Fuhrer, J., Egger, A., Lehnherr, B., Grandjean, A., Tschannen, W., 1989. Effects of ozone on the yield of spring wheat (Triticumaestivum L., cv. Albis) grown in open-top field chambers. Environ. Pollut. 60, 273-289.

Fuhrer, J., Grimm, A.G., Tschannen, W., Shariatmadari, H., 1992. The response of spring wheat (Triticum aestivum L.) to ozone at higher elevations. 2. Changes in yield, yield components and grain quality in response to ozone flux. New Phytol. 121, 211-219.

Fuhrer, J., Lehnherr, B., Moeri, P.B., Tschannen, W., Shariatmadari, H., 1990. Effects of ozone on the grain composition of spring wheat grown in open-top field chambers. Environ. Pollut. 65, 181-192.

Gelang, J., Pleijel, H., Sild, E., Danielsson, H., Younis, S., Sellden, G., 2000. Rate and duration of grain filling in relation to flag leaf senescence and grain yield in spring wheat (Triticum aestivum) exposed to different concentrations of ozone. Physiol. Plant. 110, 366-375.

Gelang, J., Sellden, G., Younis, S., Pleijel, H., 2001. Effects of ozone on biomass, non-structural carbohydrates and nitrogen in spring wheat with artificially manipulated source/sink ratio. Environ. Exp. Botany 46, 155-169.

Hu, H.J., 2011. Effects of Free Air Ozone Concentration Enrichment on Absorption and Distribution of Nutrient Element in Wheat (Master thesis). Yangzhou University (in Chinese).

Kohut, R.J., Amundson, R.G., Laurence, J.A., Colavito, L., Vanleuken, P., King, P., 1987. Effects of ozone and sulfur-dioxide on yield of winter-wheat. Phytopathology 77, 71-74.

Kress, L.W., Miller, J.E., Smith, H.J., 1985. Impact of ozone on winter-wheat yield. Environ. Exp. Botany 25, 211-228.

Mishra, A.K., Rai, R., Agrawal, S.B., 2013. Differential response of dwarf and tall tropical wheat cultivars to elevated ozone with and without carbon dioxide enrichment: growth, yield and grain quality. Field Crops Res. 145, 21-32.

Mortensen, L., Engvild, K.C., 1995. Effects of ozone on C-14 translocation velocity and growth of spring wheat (Triticumaestivum L) exposed in open-top chambers. Environ. Pollut. 87, 135-140.

Mulchi, C., Rudorff, B., Lee, E., Rowland, R., Pausch, R., 1995. Morphological responses among crop species to full-season exposures to enhanced concentrations of atmospheric $\mathrm{CO}_{2}$ and $\mathrm{O}_{3}$. Water Air Soil Pollut. 85, 1379-1386.

Mulholland, B.J., Craigon, J., Black, C.R., Colls, J.J., Atherton, J., Landon, G., 1998. Growth, light interception and yield responses of spring wheat (Triticum aestivum L.) grown under elevated $\mathrm{CO}_{2}$ and $\mathrm{O}_{3}$ in open-top chambers. Glob. Change Biol. 4, 121-130.

Ojanpera, K., Leinonen, P., Yläranta, T., 1993. Effect of ozone on the grain yield of spring wheat in an open-top chamber experiment in Finland, in: Fuhrer, J., Achermann, B. (Eds.), Critical Levels for Ozone - a UN-ECE Workshop Report. UN-ECE Convention on Long-Range Transboundary Air Pollution Bern, Switzerland, pp. 248-251.

Ojanperä, K., Pätsikkä, E., Yläranta, T., 1993. Effects of low ozone exposure of spring wheat on net $\mathrm{CO}_{2}$ uptake, Rubisco, leaf senescence and grain filling. New Phytol. 138, 451-460.

Piikki, K., De Temmerman, L., Ojanpera, K., Danielsson, H., Pleijel, $\mathrm{H}$., 2008. The grain quality of spring wheat (Triticum aestivum 
L.) in relation to elevated ozone uptake and carbon dioxide exposure. Eur. J. Agron. 28, 245-254.

Pleijel, H., Danielsson, H., 2009. Yield dilution of grain $\mathrm{Zn}$ in wheat grown in open-top chamber experiments with elevated $\mathrm{CO}_{2}$ and $\mathrm{O}_{3}$ exposure. J. Cereal Sci. 50, 278-282.

Pleijel, H., Danielsson, H., Gelang, J., Sild, E., Sellden, G., 1998. Growth stage dependence of the grain yield response to ozone in spring wheat (Triticum aestivum L.). Agric. Ecosyst. Environ. 70, 61-68.

Pleijel, H., Eriksen, A.B., Danielsson, H., Bondesson, N., Selldén, G., 2006. Differential ozone sensitivity in an old and a modern Swedish wheat cultivar - grain yield and quality, leaf chlorophyll and stomatal conductance. Environ. Exp. Botany 56, 63-71. Pleijel, H., Gelang, J., Sild, E., Danielsson, H., Younis, S., Karlsson, P.E., Wallin, G., Skarby, L., Sellden, G., 2000. Effects of elevated carbon dioxide, ozone and water availability on spring wheat growth and yield. Physiol. Plant. 108, 61-70.

Pleijel, H., Ojanpera, K., Mortensen, L., 1997. Effects of tropospheric ozone on the yield and grain protein content of spring wheat (Triticum aestivum L) in the Nordic countries. Acta Agric. Scand. Sect. B-Soil Plant Sci. 47, 20-25.

Pleijel, H., Skarby, L., Wallin, G., Sellden, G., 1991. Yield and grain quality of spring wheat (Triticum-aestivum L., cv. Drabant) exposed to different concentrations of ozone in open-top chambers. Environ. Pollut. 69, 151-168.

Rai, R., Agrawal, M., Agrawal, S.B., 2007. Assessment of yield losses in tropical wheat using open top chambers. Atmos. Environ. 41, 9543-9554.

Rudorff, B.F.T., Mulchi, C.L., Daughtry, C.S.T., Lee, E.H., 1996a. Growth, radiation use efficiency, and canopy reflectance of wheat and corn grown under elevated ozone and carbon dioxide atmospheres. Remote Sens. Environ. 55, 163-173.

Rudorff, B.F.T., Mulchi, C.L., Fenny, P., Lee, E.H., Rowland, R., $1996 \mathrm{~b}$. Wheat grain quality under enhanced tropospheric $\mathrm{CO}_{2}$ and $\mathrm{O}_{3}$ concentrations. J. Environ. Qual. 25, 1384-1388.

Rudorff, B.F.T., Mulchi, C.L., Lee, E.H., Rowland, R., Pausch, R., 1996c. Effects of enhanced $\mathrm{O}_{3}$ and $\mathrm{CO}_{2}$ enrichment on plant characteristics in wheat and corn. Environ. Pollut. 94, 53-60. Sarkar, A., Agrawal, S.B., 2010. Elevated ozone and two modern wheat cultivars: an assessment of dose dependent sensitivity with respect to growth, reproductive and yield parameters. Environ. Exp. Botany 69, 328-337.

Sild, E., 1999. Impact of increasing concentrations of $\mathrm{O}_{3}$ and $\mathrm{CO}_{2}$ on wheat, clover and pasture. Institute of Botany and Ecology, University of Tartu, Estonia, pp. 5-122.

Slaughter, L.H., Mulchi, C.L., Lee, E.H., Tuthill, K., 1989. Chronic ozone stress effects on yield and grain quality of soft red winter wheat. Crop Sci. 29, 1251-1255.

Vandermeiren, K., De Temmerman, L., Staquet, A., Baeten, H., 1992. Effects of air filtration on spring wheat grown in open-top field chambers at a rural site. 2. Effects on mineral partitioning, sulfur and nitrogen-metabolism and on grain quality. Environ. Pollut. 77, 7-14.

Wang, X., Zhang, Q., Zheng, F., Zheng, Q., Yao, F., Chen, Z., Zhang, W., Hou, P., Feng, Z., Song, W., Feng, Z., Lu, F., 2012. Effects of elevated $\mathrm{O}_{3}$ concentration on winter wheat and rice yields in the Yangtze River Delta, China. Environ. Pollut. 171, 118-125.

Zhang, R.B., 2012. Effects of free air ozone concentration enrichment on grain quality and activity of related enzyme in wheat plants (Master thesis). Yangzhou University (in Chinese). Zheng, F., Wang, X., Zhang, W., Hou, P., Lu, F., Du, K., Sun, Z., 2013. Effects of elevated $\mathrm{O}(3)$ exposure on nutrient elements and quality of winter wheat and rice grain in Yangtze River Delta, China. Environ. Pollut. 179, 19-26.
Zhu, X., Feng, Z., Sun, T., Liu, X., Tang, H., Zhu, J., Guo, W., Kobayashi, K., 2011. Effects of elevated ozone concentration on yield of four Chinese cultivars of winter wheat under fully openair field conditions. Glob. Change Biol. 17, 2697-2706.

\section{References $^{1}$}

Adams, D.C., Gurevitch, J., Rosenberg, M.S., 1997. Resampling tests for meta-analysis of ecological data. Ecology 78, 1277-1283.

Avnery, S., Mauzerall, D.L., Liu, J.F., Horowitz, L.W., 2011. Global crop yield reductions due to surface ozone exposure: 1 . Year 2000 crop production losses and economic damage. Atmos. Environ. 45, 2284-2296.

Avnery, S., Mauzerall, D.L., Fiore, A.M., 2013. Increasing global agricultural production by reducing ozone damages via methane emission controls and ozone resistant cultivar selection. Glob. Change Biol. 19, 1285-1299.

Challinor, A.J., Ewert, F., Arnold, S., Simelton, E., Fraser, E., 2009. Crops and climate change: progress, trends, and challenges in simulating impacts and informing adaptation. J. Exp. Bot. 60, 2775-2789.

Cooley, D.R., Manning, W.J., 1987. The impact of ozone on assimilate partitioning in plants: a review. Environ. Pollut. 47, 95-113.

Curtis, P.S., Wang, X.Z., 1998. A meta-analysis of elevated $\mathrm{CO}_{2}$ effects on woody plant mass, form, and physiology. Oecologia 113, 299-313.

Eckert, B., Amend, T., Belitz, H.D., 1993. The course of the Sds and Zeleny sedimentation tests for gluten quality and related phenomena studied using the light-microscope. Z. Lebensm. Unters. Forschung 196, 122-125.

EFSA, 2009. Cadmium in food. EFSA J. 980,1-139.

Feng, Z.Z., Kobayashi, K., 2009. Assessing the impacts of current and future concentrations of surface ozone on crop yield with meta-analysis. Atmos. Environ. 43, 1510-1519.

Feng, Z.Z., Kobayashi, K., Ainsworth, E.A., 2008. Impact of elevated ozone concentration on growth, physiology, and yield of wheat (Triticum aestivum L.): a meta-analysis. Glob. Change Biol. 14, 2696-2708.

Fuhrer, J., Lehnherr, B., Moeri, P.B., Tschannen, W., Shariatmadari, H., 1990. Effects of ozone on the grain composition of spring wheat grown in open-top field chambers. Environ. Pollut. 65, 181-192.

Fuhrer, J., Skarby, L., Ashmore, M.R., 1997. Critical levels for ozone effects on vegetation in Europe. Environ. Pollut. 97, 91-106.

Gelang, J., Pleijel, H., Sild, E., Danielsson, H., Younis, S., Sellden, G., 2000. Rate and duration of grain filling in relation to flag leaf senescence and grain yield in spring wheat (Triticum aestivum) exposed to different concentrations of ozone. Physiol. Plant. 110, 366-375.

Grandjean, A., Fuhrer, J., 1989. Growth and leaf senescence in spring wheat (Triticum-aestivum) grown at different ozone concentrations in open-top field chambers. Physiol. Plant. 77, 389-394.

Grunhage, L., Braden, H., Bender, J., Burkart, S., Lehmann, Y., Schroder, M., 2011 Evaluation of the ozone-related risk for winter wheat at local scale with the CRO3PS model. Gefahrst. Reinhalt. Der Luft 71, 90-97.

Hedges, L.V., Gurevitch, J., Curtis, P.S., 1999. The meta-analysis of response ratios in experimental ecology. Ecology 80, 1150-1156.

Hruskova, M., Skodova, V., Blazek, J., 2004. Wheat sedimentation values and falling number. Czech J. Food Sci. 22, 51-57.

Kibite, S., Evans, L.E., 1984. Causes of negative correlations between grain yield and grain protein concentration in common wheat. Euphytica 33, 801-810.

Kindred, D.R., Gooding, M.J., Ellis, R.H., 2005. Nitrogen fertilizer and seed rate effects on Hagberg falling number of hybrid wheats and their parents are associated with alpha-amylase activity, grain cavity size and dormancy. J. Sci. Food Agric. 85, 727-742.

Lobell, D.B., Gourdji, S.M., 2012. The influence of climate change on global crop productivity. Plant Physiol. 160, 1686-1697.

Lunn, G.D., Major, B.J., Kettlewell, P.S., Scott, R.K., 2001. Mechanisms leading to excess alpha-amylase activity in wheat (Triticum aestivum, L) grain in the UK. J. Cereal Sci. 33, 313-329.

Manley, M., Engelbrecht, M.L., Williams, P.C., Kidd, M., 2009. Assessment of variance in the measurement of hectolitre mass of wheat, using equipment from different grain producing and exporting countries. Biosyst. Eng. 103, 176-186.

Mills, G., Buse, A., Gimeno, B., Bermejo, V., Holland, M., Emberson, L., Pleijel, H., 2007. A synthesis of AOT40-based response functions and critical levels of ozone for agricultural and horticultural crops. Atmos. Environ. 41, 2630-2643.

Mulholland, B.J., Craigon, J., Black, C.R., Colls, J.J., Atherton, J., Landon, G., 1997. Impact of elevated atmospheric $\mathrm{CO}_{2}$ and $\mathrm{O}_{3}$ on gas exchange and chlorophyll content in spring wheat (Triticum aestivum L.). J. Exp. Bot. 48, 1853-1863.

Pleijel, H., 2011. Reduced ozone by air filtration consistently improved grain yield in wheat. Environ. Pollut. 159, 897-902.

Pleijel, H., 2012. Effects of ozone on zinc and cadmium accumulation in wheat dose-response functions and relationship with protein, grain yield, and harvest index. Ecol. Evol. 2, 3186-3194.

Pleijel, H., Eriksen, A.B., Danielsson, H., Bondesson, N., Selldén, G., 2006. Differential

\footnotetext{
${ }^{1}$ References used for the general text.
} 
ozone sensitivity in an old and a modern Swedish wheat cultivar-grain yield and quality, leaf chlorophyll and stomatal conductance. Environ. Exp. Bot. 56, 63-71.

Pleijel, H., Uddling, J., 2012. Yield vs. quality trade-offs for wheat in response to carbon dioxide and ozone. Glob. Change Biol. 18, 596-605.

Reeves, S.G., Baxter, E.D., Martin, H.L., Wainwhright, T., 1978. Prediction of the malting quality of barley by a modified zeleny sedimentation test. J. Inst. Brew. $85,141-143$.

Rosenberg, M.S., Adams, D.C., Gurevitch, J., 2000. MetaWin: Statistical Software for Meta-analysis, Version 2.0. Sinauer Associates, Inc, Sunderland, MA, USA.

Salt, D.E., Prince, R.C., Pickering, I.J., Raskin, I., 1995. Mechanisms of cadmium mobility and accumulation in Indian mustard. Plant Physiol. 109, 1427-1433.

Sandelius, A., Naslund, K., Carlsson, A., Pleijel, H., Sellden, G., 1995. Exposure of spring wheat (Triticum-aestivum) to ozone in open-top chambers - effects on acyl lipid-composition and chlorophyll content of flag leaves. New. Phytol. 131, 231-239.

Sarkar, A., Agrawal, S.B., 2010. Elevated ozone and two modern wheat cultivars: an assessment of dose dependent sensitivity with respect to growth, reproductive and yield parameters. Environ. Exp. Bot. 69, 328-337.

Satarug, S., Garrett, S.H., Sens, M.A., Sens, D.A., 2010. Cadmium, environmental exposure, and health outcomes. Environ. Health Perspect. 118, 182-190.

Simpson, D., Arneth, A., Mills, G., Solberg, S., Uddling, J., 2014. Ozone - the persistent menace: interactions with the $\mathrm{N}$ cycle and climate change. Curr. Opin. Environ. Sustain. 9, 9-19.

Soja, G., Barnes, J.D., Posch, M., Vandermeiren, K., Pleijel, H., Mills, G., 2000 Phenological weighting of ozone exposures in the calculation of critical levels for wheat, bean and plantain. Environ. Pollut. 109, 517-524.

Tai, A.P.K. Val Martin, M., Heald, C.L., 2014. Threat to Future Global Food Security from Climate Change and Ozone Air Pollution. Nature Climate Change 4, 817-821.

Van Dingenen, R., Dentener, F.J., Raes, F., Krol, M.C., Emberson, L., Cofala, J., 2009. The global impact of ozone on agricultural crop yields under current and future air quality legislation. Atmos. Environ. 43, 604-618.

Vandermeiren, K., De Temmerman, L., Staquet, A., Baeten, H., 1992. Effects of air filtration on spring wheat grown in open-top field chambers at a rural site. 2. Effects on mineral partitioning, sulfur and nitrogen-metabolism and on grain quality. Environ. Pollut. 77, 7-14.

Vingarzan, R., 2004. A review of surface ozone background levels and trends. Atmos. Environ. 38, 3431-3442.

Volz, A., Kley, D., 1988. Evaluation of the Montsouris series of ozone measurements made in the 19th-century. Nature 332, 240-242.

Wang, Y.X., Frei, M., 2011. Stressed food - the impact of abiotic environmental stresses on crop quality. Agric. Ecosyst. Environ. 141, 271-286.

Weiss, A., Moreno-Sotomayer, A., 2006. Simulating grain mass and nitrogen concentration in wheat. Eur. J. Agron. 25, 129-137.

Zheng, F. Wang, X., Zhang, W., Hou, P., Lu, F., Du, K., Sun, Z., 2013. Effects of elevated $\mathrm{O}(3)$ exposure on nutrient elements and quality of winter wheat and rice grain in Yangtze River Delta, China. Environ. Pollut. 179, 19-26.

Zhu, X., Feng, Z., Sun, T., Liu, X., Tang, H., Zhu, J., Guo, W., Kobayashi, K., 2011. Effects of elevated ozone concentration on yield of four Chinese cultivars of winter wheat under fully open-air field conditions. Glob. Change Biol. 17, 2697-2706. 